\title{
The Empowerment of Social Capital in the Malay Traditional Settlement
}

\author{
Nur 'Adilah Hassan'1, Nor Zalina Harun², Noordeyana Tambi \\ 1,2 Institute of Malay World and Civilization, \\ ${ }^{3}$ Faculty of Social Science and Humanities, \\ The National University of Malaysia, Malaysia \\ nuradilahhassan6@gmail.com; nzalina@ukm.edu.my; deyana@ukm.edu.my
}

\begin{abstract}
Good social capital development allows for discussions to explore what make a self-sustaining settlement by the locals. This kind of discussions includes the opportunity to speak out and to be part of a development process that involved in the local settlement. However, many issues have been identified towards making sustainable community developments a success, especially in settlement with a high heritage values. This paper seeks to devise solutions to issues identified with regard to development occurred in Kuala Terengganu. Knowledge of these issues may provide a useful guide for future social capital developments in a place with high heritage values.

Keywords: sustainability; social capital; local community, heritage, traditional settlement

eISSN 2514-751X @ 2019. The Authors. Published for AMER ABRA cE-Bs by e-International Publishing House, Ltd., UK. This is an open-access article under the CC BY-NC-ND license (http://creativecommons.org/licenses/by$n c-n d / 4.0 /$ ). Peer-review under responsibility of AMER (Association of Malaysian Environment-Behaviour Researchers), ABRA (Association of Behavioural Researchers on Asians) and $c E-B s$ (Centre for EnvironmentBehaviour Studies), Faculty of Architecture, Planning \& Surveying, Universiti Teknologi MARA, Malaysia. DOI: https://doi.org/10.21834/aje-bs.v4i13.345
\end{abstract}




\subsection{Introduction}

Sustainable development has become an essential indicator at every level of development planning. This concept is closely related to humanity as they have the ability to create and produce sustainable development that enhances social and economic productivity hence elevate the quality of life. Malaysia is one of the ASEAN countries that has implemented the concept to protect the environmental system and social capital at the local level. In the context of Malaysia, social capital is reffered as an essential mechanism in the formation of social communities by promoting the preservation of local identity. While in most developing countries, social capital development acts a social transformation platform to improve and enhance the social capital of local communities. The developments in this sense aimed at improving the living standards of local communities to achieve environmental, economic, and social sustainability with mutual interest. However, many issues have been identified towards making social capital development a success, especially in the settlement areas with high heritage value. These issues seems to be the main factors that limit the success of a community thus constrain the development of a more sustainable traditional settlement. Therefore, this study aims to identify the issues in the development of sustainable communities in the context of traditional settlements so that Malaysia can achieve the aspirations of sustainable developments for the traditional settlements in particular.

\subsection{Literature Review}

The collapse of the natural systems as a consequence of the massive physical development gave realisation to society and the policymakers regarding the essential concept of sustainable development. The idea has become the primary focus of both local and international conferences as it affects the environment and social aspects of society. Hence, in 1987, the Brundtland Commission Report was introduced as one of the solutions to resolve the issues and problems as well as to provide the needs of the present and future generations (Nocca, 2017). According to the Brundtland Commission Report 1987, the concept of sustainable development is defined as development that aims to enhance and achieve the environmental, economic and the social improvement of the society both locally and globally. This process binds together the protection and enhancement of natural resources with the economic and social requirements to meet the needs of the present and future generation (World Commission on Environment and Development, 1987). This concept emphasises the role of development which ensures satisfaction without compromising both the current and future generation's needs. The Rio Earth Summit in 1992 discussed the action plan to implement this concept. This conference established the principle of sustainable development based on three crucial factors, namely environmental protection, economic growth and most importantly, social development. Thus, in line with the Rio Earth Summit, Malaysia began to introduce the concept of sustainable development in order to protect the welfare, quality of life, and social capital of local communities that were seen to be increasingly threatened by unplanned physical development (Mokthsim and Salleh, 2014; Harun et al., 2014). Concerning the association between social capital and sustainable 
development, studies have identified three main categories of social capitals which are: 1) bonding social capital, 2) bridging social capital and 3) linking social capital (Murzyn-Kupisz \& Dzialek, 2013; Claridge, 2018) (Refer to Figure 1). The first, which includes the strong relationship that evolves between individuals in the similar social group (network closure), is defined as a bonding social capital, while the bridging social capital is described as a relationship that connects people across different social groups which typically cleaves society such as religion and race (Claridge, 2018). Lastly, linking social capital refers to the connection between individuals or groups in different social strata in a hierarchy (Claridge, 2018). However, the study solely focuses on the bonding social capital in relation to the preservation efforts of the traditional settlements.

\subsection{Bonding Social Capital}

The bonding social capital is closely related to networks with a high density of relationships between the community members in traditional settlements (Claridge, 2018). Every member in the community network is closely interconnected as they always interact frequently and they are acquainted amongst each other. Each of the community members shares the values and has the common understandings which enable them to trust and work together. Usually, this type of social capital includes family, friends, and neighbours whom they can provide material as well as emotional support. According to Lev Vygotsky, (1997), there are two crucial components which can describe more on the relationship between the bonding social capital and traditional settlement, which are: 1) social networks and 2) the local heritage. Both components are interrelated in determining the success of the preservation of the traditional settlements. The traditional settlement was formed with unique features, whereby one of them is the tangible heritage. The tangible heritage such as squares, beach, mosques, waterfronts, and jetty function as a medium for the local community to create activities which eventually builds their trust, reciprocity, mutuality, and responsibility among the social groups (Murzyn-Kupisz \& Dzialek, 2013). The integration between the local communities will develop cooperation between the members and create a sense of willingness to sacrifice for others. As a result, the social capital among the local community becomes stronger which tends to develop a sense of attachment, belonging, as well as the values of the local community identity (refer to Figure 1). Hence, the preservation and conservation effort of the traditional settlements are very crucial as it will affect the robustness of bonding social capital of the local community.

\subsubsection{Sense of Place}

The interpretation of place, according to Tuan (1974), is a "space with meaning" whereby it enacted the integration of various physical, social and cultural processes (Kolodziejski, 2014). The term "sense of place" is often used to describe the connection between people and spatial setting. The sense of place is defined as a feeling of attachments that an individual or group of people have towards their places (Ujang et al., 2015). It implies an interaction of feelings towards the place (affective), knowledge and belief (cognitive) and behaviours and actions in reference to a place (conative) (Stedman, 2002; Boerebach, 2012; Kolodziejski, 
2014). The previous study conducted by Relph (1976) has indicated that there are three major components which form a sense of place, namely: i) the physical setting of the place, ii) its activities, situations and events, iii) people's perceptions towards that place. In the context of traditional settlements, sense of place is one of the pivotal elements since it could integrate people and places. It concerns how the local communities feel, attach, and appreciate the spaces in their settlements. The traditional settlements have distinctive physical settings that make the place remarkable than other places (Samsudin, 2014). The waterfront, jetty and squares are the examples of the features of physical settings that would become the landmark to the settlements. The landmark is particularly one of the vital elements as it can portray the characteristics and contribute to the identities of the traditional settlements. Usually, the local community will utilise the spaces and conduct various activities. Physical activities within the spaces give a positive impact as it could trigger the social integrations (bonding social capital) among the locals (Fu et al., 2018). Over time, these integrations will consequently develop the local community's perceptions towards their settlements, as their perceptions are created through local communities' experiences and intentions in regards to their settlement. As a result, the degree of attachment, involvement and concern that local communities have for their settlement will develop a sense of place. The higher level of sense of place will sustain a place's vitality and social interaction which then contributes to the social sustainability of the local community.

\subsubsection{Sense of Belonging}

A sense of belonging refers to an individual's level of dependency and involvement with persons, groups and physical environment which will generate the feeling of being safe and comfortable at a certain place (Ahn, 2017). The sense of belonging is another level of human sense that makes people feel attached and connected to a specific place. Such sense is a higher level of sense of place whereby it discovers a determining role in any situations and spaces for people's presence to continue in the place (Sakhaeifar \& Ghoddusifar, 2016). In this regard, the people consider themselves a part of the place and imagine functions for the place in their mind based on experiences, meanings and functions which then manifest the place as essential and respectable. In relation to the traditional settlements, a sense of belonging is developed based on the level of dependency and attachment of the local community on the spaces within their settlement. It develops when space is well-identified, and the local community can feel its significance which can provide a condition to fulfil their functional needs. It can also support the behavioural goals of the community member better than a known alternative (Ujang \& Zakariya, 2015). This sense will also encourage the local community to protect their settlement (Tucunan \& Medha, 2018). The spaces such as jetty, field, beaches and house compound are the medium for the locals to develop their sense of belonging. Each of the locals has their own experiences and intentions towards the spaces which makes them feel belonged and connected to their settlement. Some of the locals depend on a certain space as it provides the network of social interactions and physical activities. Others might depend on the spaces to generate their economic incomes. Both social and economic activities consequently make them feel accepted, included and 
respected by others which automatically generate a sense of belonging among the locals (Ahn, 2017).

\subsubsection{Values of Local Community Identity}

Values have a significant influence on an individual's behaviour and attitude as well as serve as the broad guidelines in all situations. It is also simply the product of the social network interaction among the local community. This term is developed based on the relationship derived from the familiarity which is created through the passage of the time and has caused the positive outcomes in the lives of the local community. In the context of the study, the bonding social capital is the major contributor to the values of the local community identity. The interactions created among the local community can portray their local community values (Careerforce, 2015). This refers to the community's interactions through the social and economic activities which can be the platform for them to develop their community identity values. Such activities encourage the locals to interact and cooperate among each other that eventually build mutual values of the local community identity such as trust, reciprocity and altruism. Hence, these values would become the catalyst for the local community to empower the social capital in their settlement. In regards to the preservation efforts in the traditional settlements, these values are pivotal since they could become a fortress for the locals to sustain and protect community identity as well as their settlement from any unplanned physical development. Thus, the formation of the values of the local community identity seems essential as it could strengthen and maintain the local identity.

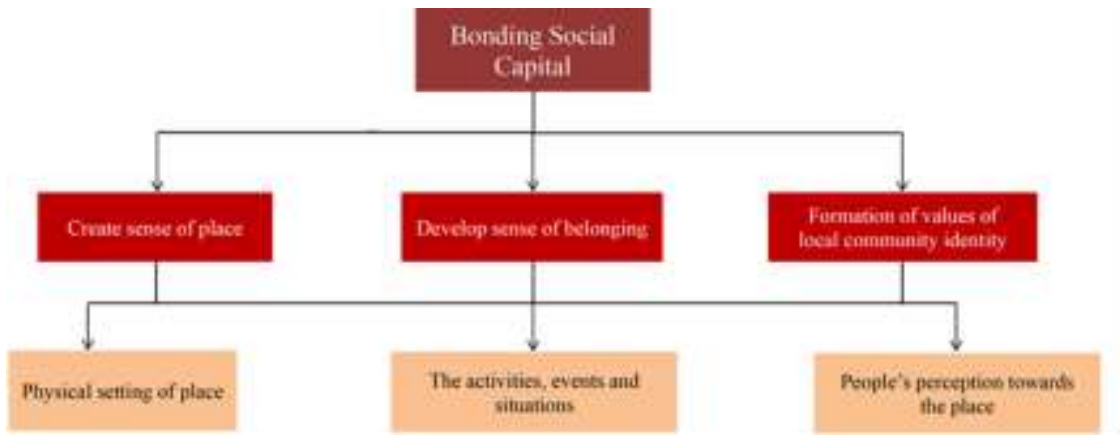

Figure 1: The components of bonding social capital

(Source: adaptation from Relph, 1976; Murzyn-Kupisz, 2013; Claridge, 2018)

However, the links between social capital and heritage frequently face many challenges. Many issues classified have become barriers to the success of sustainable preservation and conservation programs at local and international levels. Considering these aspects, this study aims to outline some of the main issues regarded as the hindrance in ensuring success in developing sustainable community development in traditional settlements in Malaysia. Thus, this study covers the two traditional settlements in Terengganu, namely Pulau Duyong Village 
and Seberang Takir Village. Pulau Duyong and Seberang Takir are fisherman villages located near to the town of Kuala Terengganu. Currently, both of these traditional villages are facing the circumstances that gradually change the ambience of the traditional settlement due to physical development. Therefore, this paper intends to assess the extent to which the new development has affected the social capital of the local community in the traditional settlement.

\subsection{Methodology}

The study adopted a qualitative approach. The data were gathered from traditional villages at Kuala Terengganu through two methods, namely site observations and semi-structured interviews. The sample of the study was the community surrounding Seberang Takir Village and Pulau Duyong Village. The selection of participants from these traditional villages were made on three reasons; i) both villages have existed before or during the British colonial period, ii) the villages are classified as an Unfederated Malay State whereby both did not accept the interference of British in their development process and iii) the local communities still exercise their traditional lifestyles and share the same physical and cultural characteristics. The checklist was prepared to guide the observation method at the selected villages. This method was used to observe the activities of the local people and identify the type of threats that affect the social capital of the locals. Apart from that, semi-structured interviews were used to obtain responses from several representative members of the local communities. The respondents were randomly selected for each of the villages. The questions of the interview were categorized based on five sections which are: i) the background of the area, ii) the types of threats that affect the social aspect of the locals, iii) the awareness of the locals on the importance of heritage, iv) the participation of the locals in the conservation programs and $v$ ) the level of willingness of the locals to participate in conservations programs. In relation to this paper, the second section is the primary focus where it could serve as the supporting evidence for the observation method. During the interview session, the terms such as heritage, sense of belonging, sense of place, and sociocultural aspects were used to capture the issues and problems occurring in both the villages.

\subsection{Results}

Based on the data gathered from both sites, the issue identified as a hindrance towards making sustainable community development success is the new development. Both of the villages are the traditional settlements that have significant physical settings, cultural and historical values which portray their social identities. However, the implementation of the new development in traditional settlements has affected the social capital of the local community. Further explanations will be discussed in the following paragraphs.

\subsection{The new development affects social capital of the local community in the traditional settlements}


The findings were derived from the analysis of the observation and interview methods collected in Pulau Duyong and Seberang Takir Village. Both methods were used to reveal the current conditions from site study areas. In the context of the study, the new development is perceived as a threat that affects the social capital of the local community.

\subsubsection{Pulau Duyong Village}

Pulau Duyong is a fisherman traditional settlement and also is well-known for its traditional boat construction centre among the local and international people. Pulau Duyong is among the villages in Kuala Terengganu that has received several incentives for heritage preservations projects. However, such incentives do not make this village prone to any new development initiatives that can vanish the unique characteristics of the village. According to the field observation, the village has gone through a lot of changes since the implementation of the new development. The illustrations (refer to Figure 2) show the changes in the village before and after the implementation of the new development.
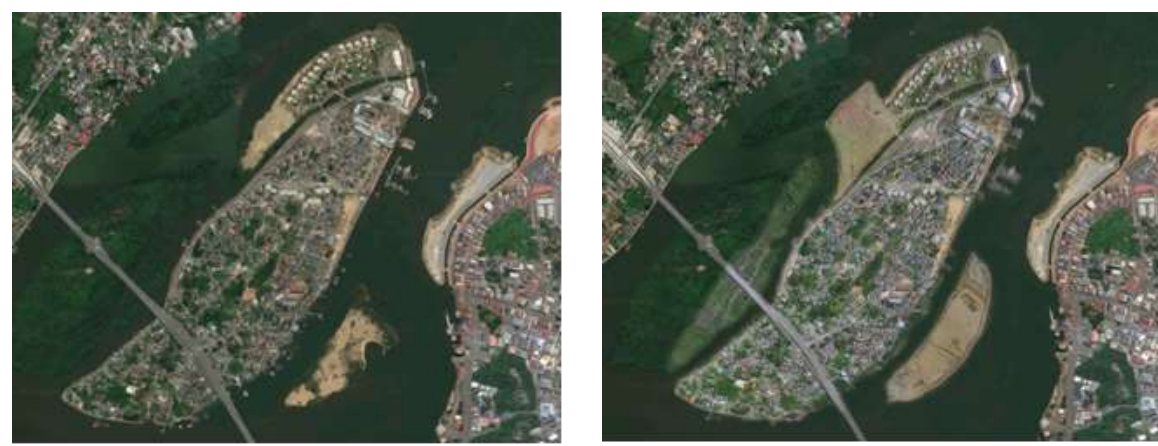

Figure 2: (a) The aerial view of the village before the implementation of the new development; (b) The aerial view ${ }^{(a)}$ of the village after the implementation of the new deblopment

(Source: (a): Google map retrieved on June 2018; (b): Drone image, captured on August 2018)

The data obtained from the field observation indicate that two ongoing developments took place at two different areas of the village (refer to Figure 2, 3 and 4). Although the development projects did not involve the residential areas of the local community, the development gradually affected the physical settings of the village. Pulau Duyong is the biggest island located at the estuary of Kuala Terengganu River. Because of this geographical condition, the village is surrounded by the mangrove area which has become one of the distinctive characteristics of the village. However, the ongoing development has already demolished one part of the physical settings of the village (refer to Figure 3 ). The new development has destroyed the mangrove areas which causes the physical settings of the village to change completely.

Besides, the village is also affected by a new development project in the south part of the village as the river was reclaimed dramatically (refer to Figure 4). The issue seems to be getting more severe as the reclaimed area is extended day by day. As expected, the 
observation found that the reclamation project has caused a decrease in the shallowness of the river. Ironically, none of the local communities knows the purpose of both development projects in their settlement. Both of the development projects not only affect the natural environments but indirectly give negative impacts towards the social capital of the local community in terms of their sense of place, sense of belonging and their values of the local community identity.

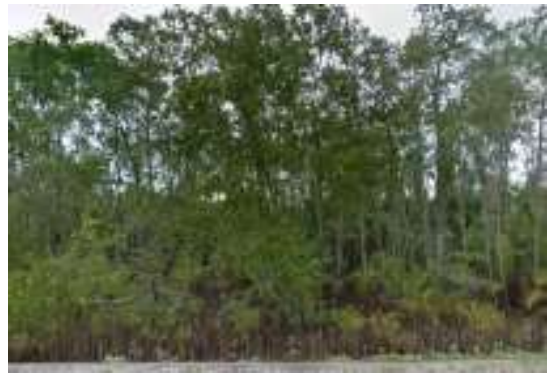

(a)

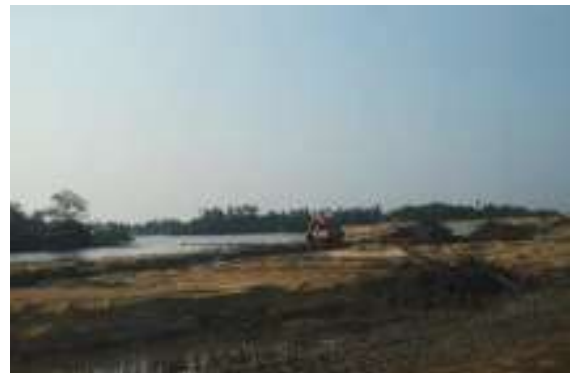

(b)

Figure 3: (a) (Before) The north part of the village before the implementation of the new development;

(b) (After) The heavy machinery being used in land clearing process.

(Source: (a): Street view retrieved on May 2018; (b): Author, captured on August 2018)

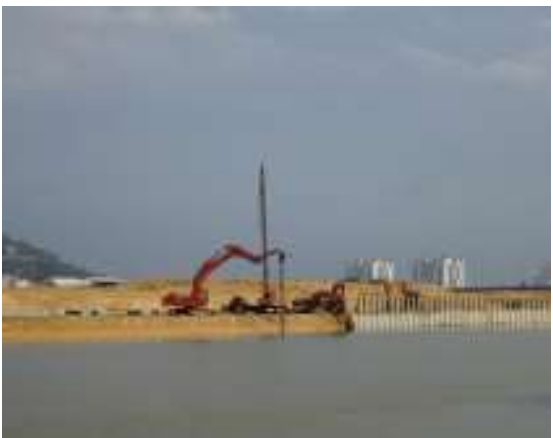

(a)

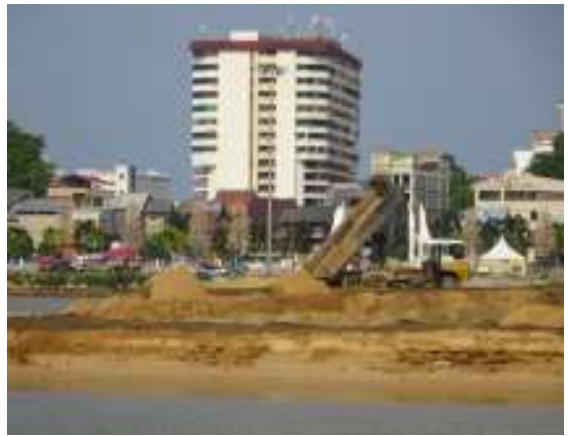

(b)

Figure 4: (a) The progress of the new development on the South part of the village as the structure being installed into the river; (b) The river reclamation activity is in progress.

(Source: Author, captured on August 2018)

Based on the observation conducted in the evening, the local communities especially the elderly will gather at the riverside and interact with each other. The local communities are physically and socially engaged in the area as they would spend their time to enjoy the sea breeze while watching the scenic views. The area is also provided with a few benches and the wooden shelter to accommodate the activity of the locals. Before the implementation of 
the reclamation project, the local community said the scenic view is breathtaking as they can see the view of Kuala Terengganu City Centre. However, the reclamation project has changed everything. A 57-year-old Malay resident expressed his feeling, who claimed:

"The new development project has become an eyesore to this village. Before the reclamation project was implemented, this area used to be an interaction spot for the locals to gather as we will enjoy the scenic view of the riverside. However, after the implementation of this project, we simply cannot enjoy beautiful views anymore. The location of this project which is located at the centre of the river has obstructed the panoramic view."

The physical setting is one of the pivotal components as it gives the identity and distinctive characters to the traditional settlements which then eventually build a sense of place and sense of belonging for the locals. According to Relph (1976), the physical setting of the area is one of the entities in the formation of a sense of place. Once the physical setting is disturbed, and even worse, demolished, the local community will be affected as they will lose their sense of place and sense of belonging. The level of attachment of the local community towards the area decreases as the values and meanings of the place gradually fade.

\subsubsection{Seberang Takir Village}

Meanwhile, Seberang Takir Village is another traditional settlement that has been affected by the new development. The village becomes vulnerable to the new development project since it is strategically located in the shoreline area. The observation revealed that the coastal area of the village has gone through massive transformations since the implementation of the new development project (Corniche Road Project) (refer to Figure 5). Corniche Road Project is the bypass highway development that connects the Airport of Sultan Mahmud with the Kuala Terengganu City Centre.

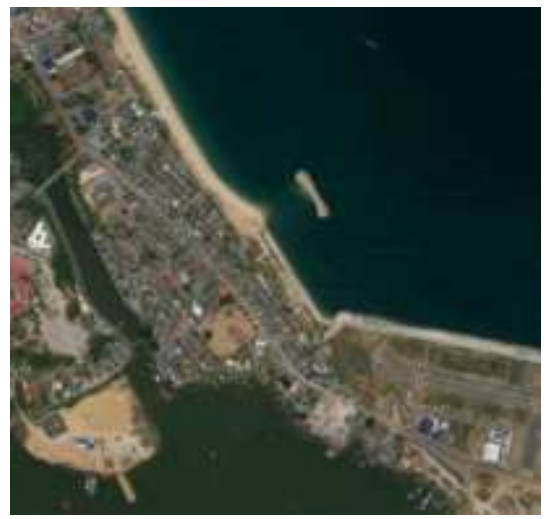

(a)

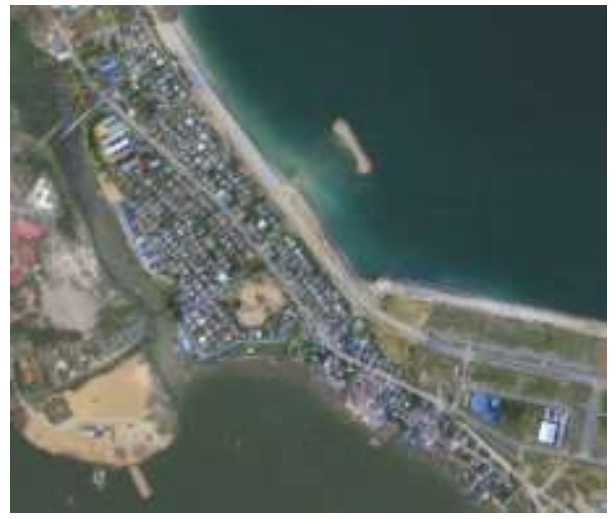

(b)

Figure 5: (a) The aerial view of the Seberang Takir Village before the implementation of the reclaimation project; (b) The aerial view of the village after the implementation of the project.

(Source: (a): Google map retrieved on June 2018; (b): Drone image, captured on August 2018) 
This haphazard development project forms significant changes to the physical settings of the village. Even worse, this development project creates a negative impact on the social capital of the local community. This refers to the physical activities of the local community as the daily activities such as relaxing under trees, swimming, picnics, and sports along the beach are affected by the new development project as there are no areas for the locals to conduct these activities anymore. A 58-year-old housewife, who lives nearby the beach, narrates the situation before and after the implementation of the project. She said:

"The beach was once the area of attraction for the local communities. Some of them would play football, swim, and also a picnic along the shore. As for me, it was a routine to come to the beach every evening to meet my friends and chit-chat together. Sometimes, I would rather sit under the trees to enjoy the breeze while watching the kids play around the beach. However, after the implementation of the Corniche Road Project, the beach has completely changed as the locals cannot play and do the activities anymore. As a result, the areas become dull as the locals no longer come to the beach as often as before".

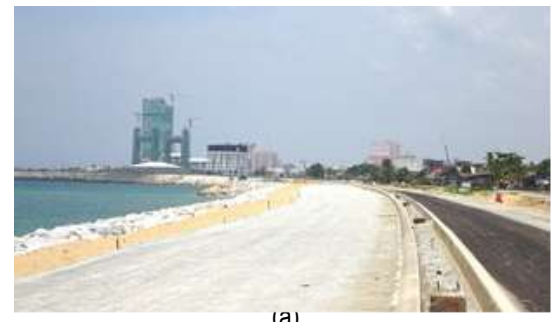

(a)

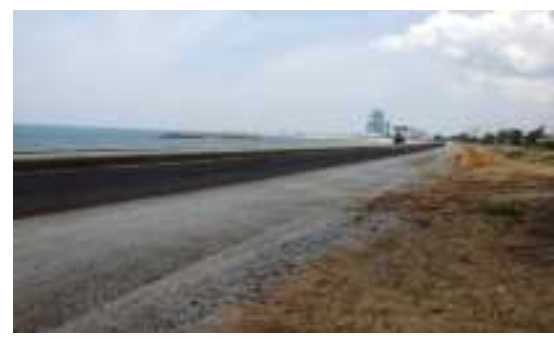

(c)

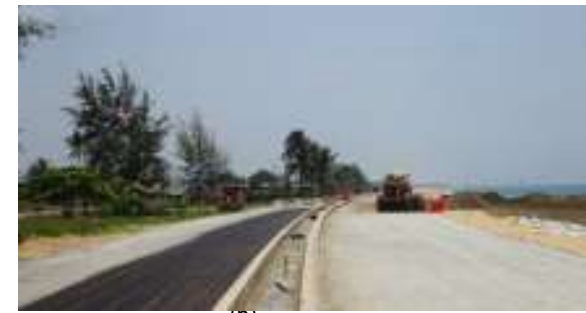

(D)

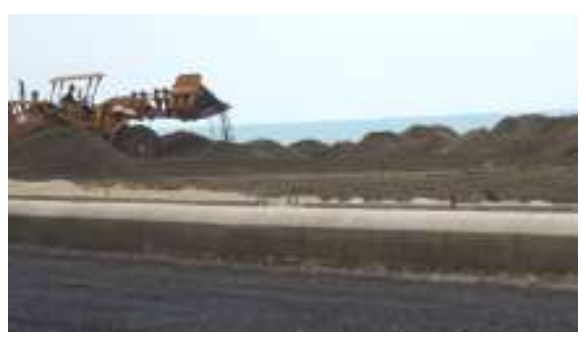

(d)

Figure 5: (a), (b), (c) and (d): The pictures show the development of Corniche Road Project along the coastal area in Seberang Takir village.

(Source: Author, captured on August 2018)

The findings from observation supported the statement as there are no open spaces along the beach area that could accommodate the daily activities of the local community. All 
the areas along the beach were paved with small stone and tarmac as to implement the twolane road (refer to Figure 6). The beach areas also were reclaimed and installed with the rock wall. This situation affects the locals as they would not be able to conduct water sport such as swimming.

Previously, the local community was dependent on the beach area as it functions as a social gathering space for the locals to meet as well as strengthen their relationship with each other. The social activities are one of the key factors to promote the social network and to enhance the bonding social capital among the community members. The interaction among the local community through various activities has given them experiences on the beach areas. As a result, the locals are physically, socially and emotionally engaged to the beach area. Over time, their experiences and perceptions towards the beach area have developed a sense of place, sense of belonging as well as the formation of the values of the local community identity. The Corniche Road Project not only has caused the degradation of the physical setting of the village but also has led to the negative implications towards the social capital of the local community. The destruction of social capital could lead to the dearth of a sense of place, a sense of belonging and values of the local community identity. The lack of sense of place in the community will lead to the formation of identity crisis which could deteriorate the quality of human capital (Tucunan \& Medha, 2018).

Undoubtedly, the new development is considered the primary issue especially in the traditional settlements since it could vanish the sense of place, the sense of belonging of the locals as well as the formation of values of the local community identity. Therefore, any development initiatives in traditional settlements must be implemented with proper planning and must take into account all included aspects especially social aspect, so that it will continually provide the positive benefits to all parties involved.

\subsection{Discussion}

This study has highlighted that the new development in traditional settlements affects the social capital of the locals. Based on the data gathered from Pulau Duyong and Seberang Takir village, it shows that the social aspect is not considered an essential component in development planning and decision-making process. The practice of centralistic traditions is the primary factor that influences this situation. The safeguarding of the social aspect is not a pivotal concern in every development as there is no proper guideline and framework are being implemented to protect the social capital of the local community. The ramifications of this action will cause the deterioration of the social capital of the locals in traditional settlements.

As this issue seems relentlessly encroaching, the authority is urged to implement a wellplanned development initiative that executes the bottom-up approach in the development process. The bottom-up approach refers to a planning model that involves the participation of all parties including the local community (Mubita et al., 2017). Through this approach, the local community would actively participate in the decision-making process. Besides, the officers involved are suggested to increase their awareness through the training and special 
course so that they will acknowledge and recognise the roles of the local community in the development planning process as it is one of the components in determining the success in the conservation of traditional settlements. The recognition and participation of the local community will consequently establish the social capital empowerment as the locals have the ability and are entitled to participate as well as influence the decisions in the development process. The participation of local community could improve the effectiveness of the development through the community ownership (Kelly and Van Vlaenderen, 1995; Kolavalli and Kerr, 2002; Claridge, 2004; Nour, 2011) whereby they tend to make better decisions and judgements in the context of their environment and circumstances (Gow and Vansant, 1983; Armeni, 2016).

Table 1: The list of issue followed by the causes, consequences and recommendations for the empowerment of the social capital.

\begin{tabular}{|c|c|c|c|c|}
\hline No & Issues & Causes/Factors & Consequences & Recommendations \\
\hline 1 & $\begin{array}{l}\text { The new } \\
\text { development affect } \\
\text { social capital of the } \\
\text { local community in } \\
\text { the traditional } \\
\text { settlements }\end{array}$ & $\begin{array}{l}\text { The practice of } \\
\text { centralistic tradtions. }\end{array}$ & $\begin{array}{l}\text { 1)The deterioration of } \\
\text { social capital of the } \\
\text { locals. } \\
\text { 2) The frailty of social } \\
\text { capital will gradually } \\
\text { cause the loss of their } \\
\text { traditional settlements } \\
\text { which then leads to: } \\
\text { 1) loss of sense of } \\
\text { belonging } \\
\text { 2) loss of sense of } \\
\text { place } \\
\text { 3) loss of the } \\
\text { intrinsic values } \\
\text { of } \\
\text { local identity }\end{array}$ & $\begin{array}{l}\text { 1)The implementation of } \\
\text { bottom-up approach in } \\
\text { the development process. } \\
\text { Hence, the local } \\
\text { community would } \\
\text { participate actively in } \\
\text { decision making process } \\
\text { (public participation } \\
\text { through objection and } \\
\text { giving opinion in planning } \\
\text { application). } \\
\text { 2)Increase the awareness } \\
\text { to the officers involved } \\
\text { through the training and } \\
\text { special course, thus they } \\
\text { will recognize the } \\
\text { important roles of locals in } \\
\text { determining the success } \\
\text { in conservation of the } \\
\text { traditional settlements. }\end{array}$ \\
\hline
\end{tabular}

(Source: Author)

Therefore, the recommendation is expected to become the driving force in empowering the social capital of the locals in the traditional settlements.

\subsection{Conclusion}

Developments are one of the tools to improve the living conditions and productivity of the people. Unfortunately, the improper planning of developments affects the cultural heritage and social capital of the local community. The threats to the social capital in the traditional settlements are slightly worrying when the enforcement efforts to protect the cultural heritage 
are in its preliminary stages. If the present trends persist, the identity of traditional settlement, as well as the social capital of the locals will be compromised or lost. It is therefore recommended for the authority to tackle the issues identified in this study should Malaysia is still committed to continuing to empower the social capital of the local community in the traditional settlements. The recommendations enumerated in this study is hoped can become the guidance to resolve the non participatory issues among of the locals in developing the traditional settlements. This is mainly because the locals are an essential generators that support and engage to flourish the settlement not the tourist neither the entrepreneurs who operate their business there. It is hoped that the findings and recommendations of the study can provide an understanding of all parties involved (authority, academics, non-governmental organisations and local community) on the importance of the social capital empowerment as it is the significant mechanism in sustaining and preserving the traditional settlements. Wellbalanced preservation of the traditional settlements will establish a high quality of life for the local community. It is recommended that future research focuses on identifying the challenges faced by the authority in protecting the cultural heritage and social capital of the locals in traditional settlements.

\section{Acknowledgement}

This paper is made possible by the funding of Universiti Kebangsaan Malaysia under DCP Research Grant: 2017-008/4.

\section{References}

Ahn, M. Y. (2017). Sense of belonging as an indicator for social capital: a mixed methods analysis of students' sense of belonging to university (Doctoral dissertation, Prifysgol Bangor University).

Armeni, C. (2016). Participation in environmental decision-making: reflecting on planning and community benefits for major wind farms. Journal of Environmental Law, 28(3), 415-441.

Boerebach, J. J. (2012). Sense of place: attachement to, identity with and dependence of shopping locations.

Brundtland, G. (1987). Our common future: Report of the 1987 World Commission on Environment and Development. United Nations, Oslo, 1, 59.

Claridge, T. (2018). What is Bonding Social Capital, https://www.socialcapitalresearch.com/what-is-bonding-socialcapital/ [accessed 17 September 2018]

Claridge, T. (2018). What is Bridging Social Capital, https://www.socialcapitalresearch.com/what-is-bridging-socialcapital/ [accessed 18 September 2018]

Claridge, T. (2018). What is Linking Social Capital, https://www.socialcapitalresearch.com/what-is-linking-socialcapital/ [accessed 18 September 2018]

Claridge, T., 2004. Designing social capital sensitive participation methodologies. Report, Social Capital Research, 
Brisbane, Australia.

Community Values and Attitude. (2015). Careerforce (Community Support Services ITO Ltd), https://library.careerforce.org.nz/Learning\%20Assessment\%20Resources/LG28523-1.0.pdf [accessed on 8 January 2019]

Fu, C., Wang, C., Yang, F., Cui, D., Wang, Q., \& Mao, Z. (2018). Association between social capital and physical activity among community-dwelling elderly in Wuhan, China. International Journal of Gerontology, 12(2), 155-159.

Gow D, Vansant J (1983) Beyond the rhetoric of rural development participation: How can it be done? World Development 11, 427-443.

Harun, N. Z., Zakariya, K., Mansor, M., \& Zakaria, K. (2014). Determining attributes of urban plaza for social sustainability. Procedia-social and behavioral sciences, 153, 606-615.

Kelly K, Van Vlaenderen H (1995) Evaluating participation processes in community development. Evaluation and Program Planning 18, 371-383.

Kolavalli S, Kerr J (2002) Scaling up participatory watershed development in India. Development \& Change 33, 213235.

Kolodziejski, A. L. (2014). Connecting People and Place: Sense of Place and Local Action.

Mokthsim, N., \& Salleh, K. O. (2014). Malaysia's Efforts toward Achieving a Sustainable Development: Issues, Challenges and Prospects. Procedia-Social and Behavioral Sciences, 120, 299-307.

Mubita, A., Libati, M. \& Mulonda, M. (2017). The Importance and Limitations of Participation in Development Projects and Programmes. European Scientific Journal, 13(5), 238-251.

Murzyn-Kupisz, M., \& Działek, J. (2013). Cultural heritage in building and enhancing social capital. Journal of Cultural Heritage Management and Sustainable Development, 3(1), 35-54.

Nocca, F. (2017). The role of cultural heritage in sustainable development: Multidimensional indicators as decisionmaking tool. Sustainability, 9(10), 1882.

Nour, A. M. (2011). Challenges and advantages of community participation as an approach for sustainable urban development in Egypt. Journal of sustainable development, 4(1), 79.

Relph, E. (1976). Place and placelessness (Vol. 1). Pion.

Sakhaeifar, A., \& Ghoddusifar, S. H. (2016). Impact of Location-Behavior on Sense of Belonging to Place. Modern Applied Science, 10(5), 57.

Samsudin, N. A. (2014, August). The Physical Design Attributes of Traditional Malay Kampong in Kampung Tanjung Bunut, Kuala Terengganu. In 5th International Graduate Conference on Engineering, Science \& Humanity (pp. 1921).

Stedman, R. C. (2002). Toward a social psychology of place: Predicting behavior from place-based cognitions, attitude, and identity. Environment and behavior, 34(5), 561-581.

Summit, E. (1992). Agenda 21. The United Nations programme for action from Rio.

Tuan, Y. F. (1974). Topophilia (p. 260). 
Hassan, N.A., et.al. / Asian Journal of Environment-Behaviour Studies (ajE-Bs), 4(13) May / Aug 2019 (pp.15-29)

Tucunan, K. P., \& Medha, A. N. (2018, November). Social sustainability indicators in kampung; dialogue between Ibn Khaldun's Tamadun concepts and sustainable developments approaches. In IOP Conference Series: Earth and Environmental Science (Vol. 202, No. 1, p. 012073). IOP Publishing.

Ujang, N., \& Zakariya, K. (2015). The notion of place, place meaning and identity in urban regeneration. Procediasocial and behavioral sciences, $170,709-717$.

Ujang, N., Moulay, A., \& Zakariya, K. (2015). Sense of well-being indicators: Attachment to public parks in Putrajaya, Malaysia. Procedia-Social and Behavioral Sciences, 202, 487-494.

Vygotsky, L. S. (1997). The collected works of LS Vygotsky: Problems of the theory and history of psychology (Vol. 3). Springer Science \& Business Media.

World Commission on Environment and Development (WCED). (1987). Our Common Future, UN Documents Cooperation Circles, http://www.un-documents.net/wced-ocf.htm, [accessed 12 April 2018] 